International Journal of Physical Research, $8(1)(2020) 22-26$
SPC
Website: $w$ ww. sciencepubco.com/index.php/IJPR
Research paper

\title{
A study on the correlation potential of compaction characteristics and atterberg limits of selected lateritic soils
}

\author{
G. O. Adunoye ${ }^{1}$, A. A. Ojo ${ }^{1}$, A. F. Alasia ${ }^{1}$, M. O. Olarewaju ${ }^{1}$ \\ ${ }^{1}$ Department of Civil Engineering, Obafemi Awolowo University, Ile-Ife, Nigeria \\ *Corresponding author E-mail: kayadunoye@yahoo.com
}

\begin{abstract}
The importance of soil compaction for civil engineering construction and application cannot be over-emphasised. To perform soil compaction, numerous number of samples are required, with considerable time and laborious laboratory activities. This has necessitated the need to find models for the prediction of compaction characteristics, using easily determined soil properties. This work therefore undertook a study of the correlation potential of compaction characteristics and Atterberg limits of soils, with a view to modelling compaction characteristics, using Atterberg limits. To achieve this aim, soil samples were obtained from selected locations within Obafemi Awolowo University campus, Ile-Ife, Nigeria. Preliminary, Atterberg limits and compaction tests were conducted on the soil samples, using standard procedure. Using Microsoft Excel and Xuru's Regression tool, the laboratory test results were used to develop relationships between compaction characteristics (optimum moisture content and maximum dry density) and Atterberg limits (liquid limit and plastic limit). Results showed that the natural moisture content of soil samples ranged between $4.97 \%$ and $19.72 \%$; liquid limit ranged between $27 \%$ and $68 \%$; plastic limit ranged between $18.92 \%$ and $63.01 \%$; and plasticity index ranged between $0.94 \%$ and $14.63 \%$. The optimum moisture content ranged between $6.7 \%$ and $27 \%$, while the maximum dry density ranged between $1560 \mathrm{kN} / \mathrm{m} 3$ and $2260 \mathrm{kN} / \mathrm{m} 3$. The results of regression analysis showed that the combination of liquid limit and plastic limit has a strong correlation with optimum moisture content $(\mathrm{R} 2=0.870)$; while the combination (of liquid limit and plastic limit) showed a weak correlation with maximum dry density (R2 $=0.150$ ). The study concluded that liquid limit and plastic limit could be used to estimate the optimum moisture content of the soils, by applying the developed relationship/equation.
\end{abstract}

Keywords: Compaction; Dry Density; Liquid Limit; Optimum Moisture Content; Plastic Limit.

\section{Introduction}

Compaction of soil as an act of pressing the soil particles tightly together by expelling air from the void spaces (Das 2006). In other words, compaction is a process of densifying the soil by application of stress which causes expulsion of air in the interstices of soil mass. It is one of the important geotechnical engineering applications in the development of civil engineering projects - construction of roads, airfield pavement, railway, flyovers retaining structures, dams and many land reclamation works. It affords the engineer the opportunity of densifying soils to enhance its strength and reduce its compressibility and hydraulic conductivity. Furthermore, the purpose of compacting earth fills such as earth dams and embankments (highway, railway and canal) is to produce a soil mass that will satisfy the two basic criteria: reduction in settlement, and increase in shear strength and strength characteristics (which in turn increases the bearing capacity of foundations constructed over the soils). Compaction also increases the stability of slopes and also reduces the permeability of soil. It is used in waste impoundment sites to make them relatively impermeable to leachates and thus reduce the threat of groundwater contamination. The importance of compaction is further underscored by the fact that, out of the different methods of soil improvement on site, it is usually the least expensive and the most widely used (Sridharan and Nagaraj 2003; Ratnam and Prasad 2019).

In assessing the suitability of the soil with respect to compaction, compaction characteristics are used in the interpretation of the results. Since compaction of soil has applications in almost every field of civil engineering involving soil, it is very essential for a civil engineer to know the compaction characteristics of natural soils, and thereby assess their suitability (Tsegay et al. 2017). There are two compaction characteristics: optimum moisture content (OMC) and maximum dry density (MDD). In compaction, certain amount of water is added to the soil to act as a lubricant and allow soil particles to be effectively packed together (BS 1377 1990; Liu and Evett 2004). For a particular compaction effort, there is a particular moisture content, beyond which the soil density reduces. In other words, there is a particular moisture content which gives the greatest dry density. This pair of values are referred to as optimum moisture content (OMC) and maximum dry density (MDD) respectively. (Gofar and Kassim 2008; Ratnam and Prasad 2019).

Laboratory compaction (for the determination of OMC and MDD) of soils involves collection of numerous samples, laborious efforts, and considerable time. Therefore, for a preliminary assessment of the suitability of soils for large projects, it is desirable to develop correlations 
of engineering properties (compaction characteristics in this case) with simple physical properties (such as Atterberg limits), which are easily determined through simple tests (AASHTO 2003; Tsegay et al. 2017). As reported by Faizah (2005), several studies have indicated that there is a relationship between the compaction characteristics and Atterberg limits. This relationship can be used to estimate the values of MDD and OMC based on Atterberg limits without having to perform the laboratory compaction test. According to Ratnam and Prasad (2019), attempts have also been made in the past to correlate the compaction characteristics with the liquid limit; but such correlations appear to be less than satisfactory. .

One of the first attempts to relate compaction characteristics with index properties was by Jumikis (1946). He developed a correlation equation to estimate OMC with liquid limit and plasticity index. Since then, several continuous attempts have been made by researchers to predict compaction characteristics with simple physical and index properties.

Johnson and Sallberg (1962) developed a chart to predict only the OMC without suggesting any correlative chart or method to predict MDD. Pandian et al. (1997) also predicted the compaction characteristics of soil in terms of liquid limit alone.

Blotz et al. (1998) reported that a linear relationship exists between the maximum dry unit weight and the base 10 logarithm of compaction energy based on the tests conducted on a micaceous silty fine sand. Faizah (2005) reported that there are linear relationships between the compaction parameters (MDD and OMC) and the Atterberg limits (liquid limit - LL, plastic limit - PL and plasticity index - PI)), which may be expressed in the form: MDD $=2.132-0.004 \mathrm{LL}-0.006 \mathrm{PL}\left(\mathrm{R}^{2}=0.588\right)$; OMC $=4.065+0.125 \mathrm{LL}+0.180 \mathrm{PL}\left(\mathrm{R}^{2}=0.517\right)$.

Mohd and Che (2005) also investigated the relationship between the compaction characteristics and Atterberg limits and reported linear relationships between the compaction characteristics and Atterberg limits as shown by the following equations: OMC = 0.079LL+0.24PL+3.577 $\left(\mathrm{R}^{2}=0.458\right)$; MDD = -0.003LL+0.007PL+2.137 $\left(\mathrm{R}^{2}=0.496\right)$.

Raju et al. (2014) investigated the functional correlations between compaction characteristics, un-drained shear strength and Atterberg limits of soils of Tirupati region of Andhra Pradesh. They observed that there exists a definite relationship between modified plasticity index and undrained shear strength. They also concluded that the MDD changes as Modified Plasticity Index (MPI), and developed the following equations from the relationships: OMC $=0.233 \mathrm{MPI}+8.00\left(\mathrm{R}^{2}=0.979\right)$; $\mathrm{MDD}=-0.035 \mathrm{MPI}+18.49\left(\mathrm{R}^{2}=0.0976\right)$.

Idris et al. (2014) modelled and predicted compaction parameters based on Atterberg limits and clay content. They used a modeling technique to determine the soil compaction characteristics from Atterberg limits and clay content. Their study showed that the MDD and OMC of the soil samples could be estimated from the soils' Atterberg limits and the fine particle contents. They also concluded that their models showed an improvement over other existing models by giving a better correlation among the parameters modelled. For the OMC, even though the model developed in this study shows a better R-square value, the test results have indicated an almost equal capability to estimate the OMC by each of the three models, hence the fine particle content has little or no influence in the determination of the OMC. They proposed the following equations: $\mathrm{MDD}=-2.035 \mathrm{LL}+2.034 \mathrm{PL}+2.033 \mathrm{PI}-.004 \mathrm{~F}+2.142\left(\mathrm{R}^{2}=0.9604\right) ; \mathrm{OMC}=-92.092 \mathrm{LL}+92.521 \mathrm{PL}+$ 92.189PI + 0.179F $-4.74\left(\mathrm{R}^{2}=0.8628\right)$.

Tsegay et al. (2017) studied the correlation between compaction characteristics and Atterberg limits of fine-grained soils in Addis Ababa, using regression analysis. They concluded that there was a relatively good correlation between OMC and PL. Similarly a good correlation was observed between MDD and LL, PL and PI together. They presented the following equations for the developed relationships: OMC = $0.916 * \mathrm{PL}-0.030 * \mathrm{PI}-0.875,\left(\mathrm{R}^{2}=0.8072\right) ; \mathrm{MDD}=-0.18^{*} \mathrm{PL}-0.027 * \mathrm{PI}+21.182\left(\mathrm{R}^{2}=0.835\right)$.

Ratnam and Prasa (2019) predicted the compaction and compressibility characteristics of compacted soils. From their results they concluded as follows: the OMC is a function of modified PL; the MDD obtained is dependent on modified PL and representative grain size index; the compression index $(\mathrm{Cc})$ is found to be linearly related to modified LL; the swelling index is directly proportional to modified LL; the ratio of compression index and swelling index is inversely proportional to modified LL; the swelling pressure is directly proportional to the swelling index.

As at the time of carrying out this study, there was no documented evidence of correlation between compaction characteristics and Atterberg limits in the study area. Hence, this study.

\subsection{Description and geology of the study area}

The study area is the Obafemi Awolowo University (OAU) campus, Ile-Ife, Southwestern Nigeria. Ile-Ife lies between Latitudes $7^{\circ} 28^{\prime} 0^{\prime}$ ' $\mathrm{N}$ and $7^{\circ} 45^{\prime} 0^{\prime} \mathrm{N}$ and Longitudes $4^{\circ} 30^{\prime} 0^{\prime}$ 'E and $4^{\circ} 34^{\prime} 0^{\prime}$ 'E. Fig. 1 is a map of OAU campus. The campus is located within the Ife-Ilesha Schist Belt. It falls within the Basement Complex area of Nigeria (Durotoye 1983). The rock types are primarily made up of Gneisses and Mica Schists into which some minor granitic and basic rocks have intruded (Boesse 1989; Adunoye et al. 2018). Fig. 2 is a geological map of OAU campus.

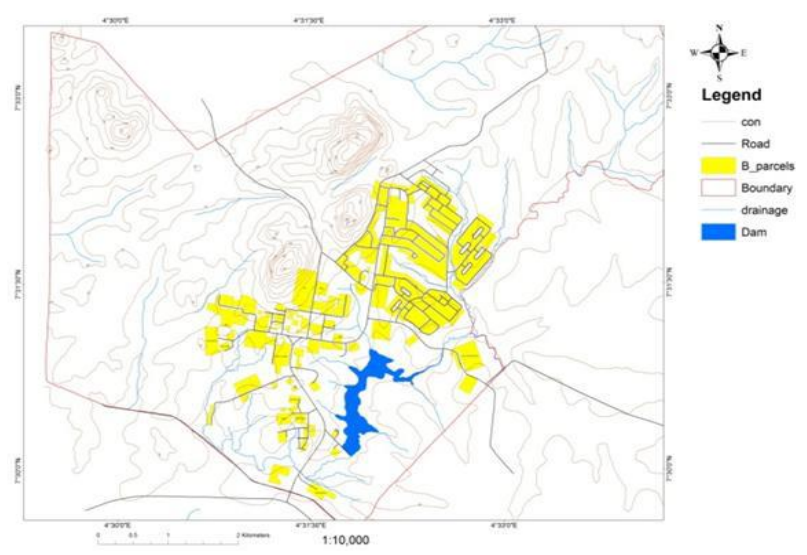

Fig. 1: Map of Obafemi Awolowo University Campus (OAU, Ile-Ife 2015). 


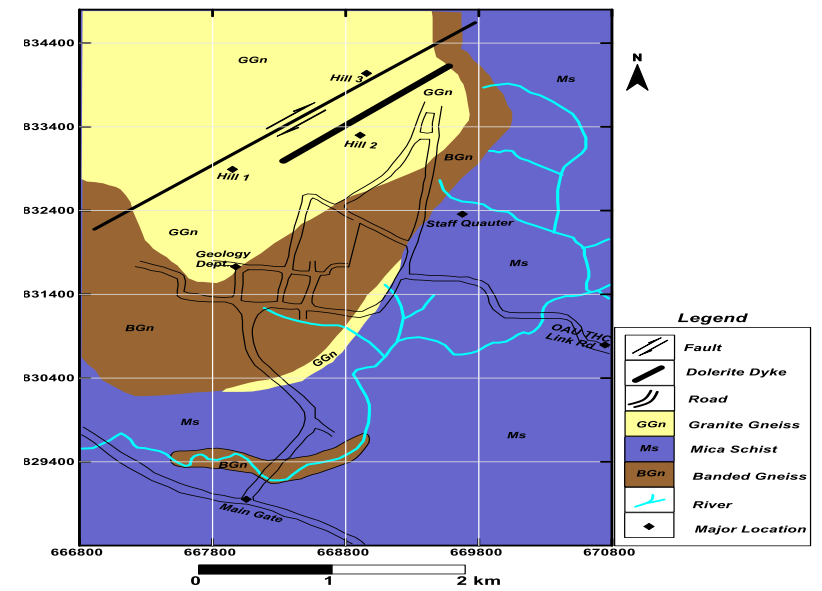

Fig. 2: Geological Map of Obafemi Awolowo University, Ile-Ife (After Boesse 1989).

\section{Materials and methods}

\subsection{Materials}

The main material used for the analysis were lateritic soil samples collected from 10 different locations within the study area (see Table 1). A sample each was collected from each location, making a total of ten collected samples.

\begin{tabular}{|c|c|c|}
\hline Sample ID & Longitude & Latitude \\
\hline S1 & $\mathrm{E} 4^{0} 31^{\prime} 28^{\prime \prime}$ & N7 $7^{0} 30^{\prime} 48^{\prime \prime}$ \\
\hline $\mathrm{S} 2$ & $\mathrm{E} 4^{0} 31^{\prime} 26.5^{\prime \prime}$ & $\mathrm{N} 7^{0} 31^{\prime} 3.5^{\prime \prime}$ \\
\hline S3 & $\mathrm{E} 4^{0} 31{ }^{\prime} 27.5$, & N7 $7^{0} 31^{\prime} 7.7^{\prime}$ \\
\hline S4 & $\mathrm{E} 4^{0} 32^{\prime} 1^{\prime \prime}$ & $\mathrm{N} 7^{0} 31^{\prime} 9.31^{\prime \prime}$ \\
\hline S5 & $\mathrm{E} 4^{0} 31^{\prime} 15.2^{\prime \prime}$ & N7031'10"' \\
\hline S6 & E4030'57'” & N7030'33", \\
\hline S7 & E4 $31^{\circ} 10.74^{\prime \prime}$ & $\mathrm{N} 7^{\circ} 31^{\prime} 06.31^{\prime \prime}$ \\
\hline S8 & $\mathrm{E} 4^{\circ} 31^{\prime} 21.43^{\prime \prime}$ & N7 $31^{\prime} 18.30^{\prime \prime}$ \\
\hline S9 & $\mathrm{E} 4^{\circ} 31^{\prime 26.69 "}$ & N7 $30^{\circ} 51.48^{\prime \prime}$ \\
\hline S10 & E4³2'23.16" & $\mathrm{N}^{\circ} 31^{\prime} 00.90^{\prime \prime}$ \\
\hline
\end{tabular}

\subsection{Soil sampling and preparation}

Soil samples were collected with the aid of the hand auger. The depth of sampling was between $0.3 \mathrm{~m}--.6 \mathrm{~m}$. About $25 \mathrm{~kg}$ of samples were collected, sealed in labelled polythene bags and immediately taken to the Geotechnical Engineering Laboratory, Department of Civil Engineering, OAU, Ile-Ife, for subsequent analyses. At the laboratory, representative samples were taken for the determination of natural moisture content. Thereafter, the remaining soils were air-dried for other laboratory tests.

\subsection{Laboratory tests on samples}

Atterberg limits and compaction tests were conducted on the soil samples, using standard procedures as outlined in BS 1377 (1990). The compaction method adopted was Stanandard Proctor. Plasticity index (PI) was determined from the determined Atterberg limits (LL and PL) using equation 1.

$\mathrm{PI}=\mathrm{LL}-\mathrm{PL}$

Where, PI = Plasticity Index

LL $=$ Liquid Limit

PL = Plastic Limit

\subsection{Investigation of relationships between compaction characteristics and atterberg limits}

Variations of compaction characteristics (OMC and MDD) and Atterberg limits (LL and PL) were studied, using excel tool. Using Xuru's regression tools (2020), relationships (equations) were developed between the following properties of the soil samples: (i) OMC and Atterberg limits, and (ii) MDD and Atterberg limits.

\section{Results and discussion}

\subsection{Preliminary tests results}

The summary of the results of test conducted on the soil samples are presented in Table 2. The natural moisture content (NMC) of soil samples ranged from $4.97 \%$ (sample S10) to $19.72 \%$ (sample S6) (see Table 2). The values of the NMC are indicative of the prevailing weather condition at the time of sample collection (Abdulazeez et al. 2020). 


\begin{tabular}{|c|c|c|c|c|c|c|}
\hline Sample ID & NMC (\%) & LL (\%) & PL (\%) & PI (\%) & $\operatorname{MDD}\left(\mathrm{kN} / \mathrm{m}^{3}\right)$ & OMC (\%) \\
\hline S1 & 17.87 & 44 & 31.91 & 12.09 & 1570 & 27 \\
\hline S2 & 7.87 & 38 & 23.46 & 14.54 & 1722 & 22 \\
\hline S3 & 15.18 & 68 & 63.01 & 4.99 & 1850 & 6.7 \\
\hline S4 & 13.98 & 37 & 24.79 & 12.21 & 1680 & 15.55 \\
\hline S5 & 8.77 & 27 & 22.48 & 4.52 & 1900 & 13.8 \\
\hline S6 & 19.72 & 49 & 48.06 & 0.94 & 1620 & 35 \\
\hline S7 & 12.22 & 31.55 & 18.92 & 12.63 & 1630 & 16.11 \\
\hline S8 & 10.09 & 33.6 & 18.97 & 14.63 & 1560 & 17.25 \\
\hline S9 & 10.11 & 48.64 & 34.12 & 14.52 & 1740 & 18.58 \\
\hline $\mathrm{S} 10$ & 4.97 & 38 & 25.29 & 12.71 & 2260 & 15.65 \\
\hline
\end{tabular}

The values of liquid limit (LL), plastic limit (PL) and plasticity index (PI) ranged between $27 \%$ (sample S5) and $68 \%$ (sample S3); $18.92 \%$ (sample S7) and $63.01 \%$ (sample S3); and $0.94 \%$ (sample S6) and $14.63 \%$ (sample S8) respectively (see Table 2). . According to Federal Ministry of Works and Housing Specification (1997), soils with LL not greater than $80 \%$ are suitable for sub-grade; soils with LL not greater than $35 \%$ are suitable for sub base and base course materials. On the basis of PI, soils with PI not greater than $55 \%$ are suitable for subgrade; while soils with PI not greater than $12 \%$ are suitable for use as both sub base and base course materials. It could therefore be deduced that all the soil samples are suitable for use as subgrade and earth-fill material.

The results of the compaction tests are presented (Table 2) with the values of the compaction characteristics (OMC and MDD) values of OMC ranged from $6.7 \%$ (sample S3) to $27 \%$ (sample S1). The values of MDD also ranged from $1560 \mathrm{kN} / \mathrm{m}^{3}$ (sample S8) to $2260 \mathrm{kN} / \mathrm{m}^{3}$ (sample S10). With the results of the compaction test, the soils could be said to fall between silty clay and sandy clay (O'Flaherty 1988; Bello and Adegoke 2010; Adunoye and Agbede 2013)

\subsection{Effect of Atterberg limits on compaction characteristics}

Figs. 3 and 4 are graphical representation of the variations of compaction characteristics - OMC and MDD - with Atterberg limits, respectively. It is clear that none of the Atterberg limits (LL, PL or PI) could be said to have a predicable relationship with either OMC or MDD of the soils. This necessitated a trial of the combined effects of LL and PL on the compaction characteristics. The multiple regression analysis yielded the following relationships or equations:

$\mathrm{OMC}=0.02 \mathrm{LL}^{2}-0.01 \mathrm{LL} * \mathrm{PL}+0.08 \mathrm{PL}^{2}+2.48 \mathrm{LL}+1.51 \mathrm{PL}-55.84\left(\mathrm{R}^{2}=0.870\right)$

$\mathrm{MDD}=-0.03 \mathrm{LL}^{2}+7.03 \mathrm{LL} * \mathrm{PL}-0.04 \mathrm{PL}^{2}+10.18 \mathrm{LL}-25.30 \mathrm{PL}+2080.37\left(\mathrm{R}^{2}=0.150\right)$

From the values of coefficients of determination $\left(\mathrm{R}^{2}\right)$ in equations (3) and (4), it could be said that the combination of LL and PL has a strong correlation with OMC; while the combination (of LL and PL) has a weak correlation with MDD (Shahin et al.. 2009).

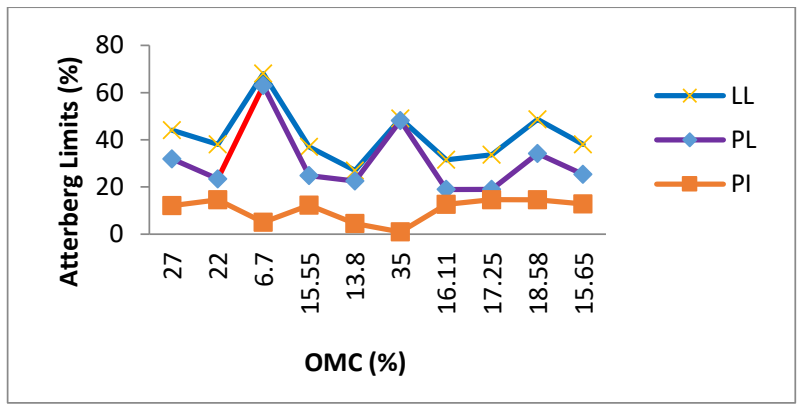

Fig. 3: Variation of OMC with Atterberg limits.

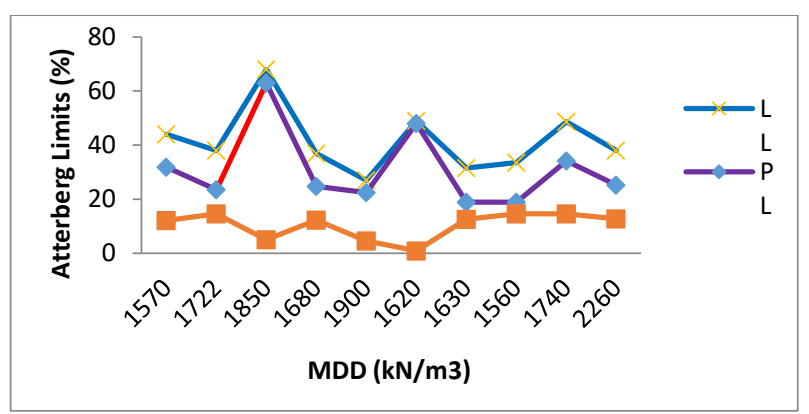

Fig. 4: Variation of MDD with Atterberg Limits.

\section{Conclusion}

Relationships between compaction characteristics (OMC and MDD) of selected soil samples had been studied. After the preliminary, Atterberg and compaction tests, the soils were found to between silty clay and sandy clay in nature and are suitable for use as sub-grade and fill material in road construction. Multiple regression analysis showed that the combination of LL and PL has a strong correlation with $\mathrm{OMC}$, and thus the generated equation could be used to predict the OMC of the selected soils. While the combination (of LL ans PL) has 
a weak correlation with MDD, thus necessitating further trial with multiple soil samples. The results of this study are valid for the selected soil samples.

\section{References}

[1] Abdulazeez MO, Adunoye GO \& Adekola AA (2020) Experimental study on the effects of some index properties on California bearing ratio of selected soils. International Journal of Scientific \& Engineering Research 11(1), 1562-1567.

[2] Adunoye GO \& Agbede OA (2013) Geotechnical evaluation of Opa dam, Obafemi Awolowo University, Ile-Ife, Nigeria. The International Journal of Engineering and Science 2(2), $160-165$.

[3] Adunoye GO, Badmus AB \& Sagbele SA (2018) Experimental investigation of the influence of gradation parameters on Atterberg limits of soil. Archives of Current Research International 15(4), 1-6. https://doi.org/10.9734/ACRI/2018/45464.

[4] American Association of State Highway and Transportation Officials (2003). User Benefit Analysis for Highways.

[5] Bello AA. Ige JA \& Tajudeen S (2007) Geotechnical characterization of lateritic soils in parts of Ejigbo Local Government Area, Southwestern Nigeria. LAUTECH Journal of Engineering and Technology 4(2), 34-38.

[6] Bello AA \& Adegoke CW (2010) Evaluation of geotechnical properties of Ilesha East Southwest Nigeria's lateritic soil. Pacific Journal of Science and Technology 11(2), 617-624.

[7] Blotz LR, Benson CH \& Boutwell GP (1998) Estimating optimum water content and maximum dry unit weight for compacted clays. Journal of Geotechnical and Geoenvironmental Engineering 124(9), 907-912. https://doi.org/10.1061/(ASCE)1090-0241(1998)124:9(907).

[8] Boesse JMA (1989) Geological Map of the Obafemi Awolowo University Campus (Unpublished), Department of Geology, Obafemi Awolowo University, Ile-Ife.

[9] British Standard. Methods of Test for Soils for Civil Engineering Properties (1990). British Standard Institution, London, UK.

[10] Das BM (2006). Principles of Geotechnical Engineering, 5th ed. Nelson, Canada.

[11] Department of Geography, Obafemi Awolowo University, Ile-Ife. Map of Obafemi Awolowo University, Ile-Ife (2015).

[12] Durotoye AB (1983) Quarternary Sediments in Nigeria. Edited by Kogbe C.A.

[13] Faizah K (2005) Estimation of Compaction Parameters Based on Atterberg Limits. M.Eng Thesis, Universiti Teknologi Malaysia, Skudai, Johor, Malaysia.

[14] Federal Ministry of Works and Housing (1997). Nigerian General Specification for Roads and Bridges (Revised Edition) 2, $137-275$.

[15] Gofar N \& Kassim KA (2008) Ground Improvement and Stabilisation. Univision Press, Selangor, Malaysia.

[16] Idris A, Waziri MI, Abdulfatah AY \& Umar M (2014) Modelling and prediction of compaction parameters based on Atterberg limits and clay content. Journal of Engineering and Technology 9(2), 24-27.

[17] Johnson AW \& Sallberg JR (1962). Factors Influencing Compaction Test Results. Highway Research Board Bulletin 319: 1-148.

[18] Jumikis AR (1946) Geology and soils of the Newark (NJ) Metropolitan Area. J. Soil Mech. Found., ASCE 93(2), 71-95.

[19] Liu C \& Evett JB (2004) Soils and Foundations. SI Edition, Prentice Hall, Singapore.

[20] Mohd R \& Che G (2005) Correlation Regression between Soil Compaction Parameters and Atterberg Limits. B.Eng. Thesis, Faculty of Civil Engineering, Universiti Teknologi Malaysia, Skudai, Johor, Malaysia.

[21] O’Flaherty CA (1988) Highway engineering 2. Edward Arnold Publishers, London, UK.

[22] Pandian NS, Nagaraj TS \& Manoj M (1997) Re-examination of compaction characteristics of fine-grained soils. Geotechnique 47(2), 363-366. https://doi.org/10.1680/geot.1997.47.2.363.

[23] Raju NV, Srimurali, M \& Prasad KN (2014) Functional correlations between compaction characteristics, un-drained shear strength and Atterberg limits. IOSR Journal of Mechanical and Civil Engineering 11(3), 109-115. https://doi.org/10.9790/1684-1134109115.

[24] Ratnam UV \& Prasa KN (2019) Prediction of compaction and compressibility characteristics of compacted soils. International Journal of Applied Engineering Research 14(3), 621-632.

[25] Shahin MA, Jaksa, MB \& Maier HR (2009) Recent Advances and Future Challenges for Artificial Neural Systems in Geotechnical Engineering Applications. Advances in Artificial Neural Systems 2009, 1-9, https://doi.org/10.1155/2009/308239.

[26] Sn MA, Jaksa MB \& Maier HR (2009) Recent Advances and Future Challenges for Artificial Neural Systems in Geotechnical Engineering Applications. Advance Artificial Neural System, Article ID 308239. https://doi.org/10.1155/2009/308239.

[27] Sridharan A \& Nagaraj HB (2005) Plastic limit and compaction characteristics of fine-grained soils. Ground Improvement 9(1), 17-22. https://doi.org/10.1680/grim.2005.9.1.17.

[28] Tsegay T, Fikre H \& Abebe T (2017) Correlation between compaction characteristics and Atterberg limits of fine-grained soil found in Addis Ababa, International Journal of Scientific \& Engineering Research 8(6), 357-364.

[29] Xuru's regression tools. Available: http://www.xuru.org. Ac4cessed on 15 April 2020. 